\title{
Resistivity and Induced Polarization applied to epithermal gold deposit in the Torre Target, at Castro Basin-PR
}

Francesco Antonelli*, LPGA-UFPR; Rodoilton Stevanato, LPGA-UFPR; Maximilian Fries, UNIPAMPA; Gustavo Correa Abreu, IGc-USP; Francisco José Fonseca Ferreira, LPGA-UFPR; Vinicius Dias Serrano, Verdau Gold

\section{Copyright 2019, SBGf - Sociedade Brasileira de Geofísica}

This paper was prepared for presentation during the $16^{\text {th }}$ International Congress of the Brazilian Geophysical Society held in Rio de Janeiro, Brazil, 19-22 August 2019.

Contents of this paper were reviewed by the Technical Committee of the $16^{\text {th }}$ International Congress of the Brazilian Geophysical Society and do not necessarily represent any position of the SBGf, its officers or members. Electronic reproduction or storage of any part of this paper for commercial purposes without the written consent of the Brazilian Geophysical Society is prohibited.

\section{Abstract}

Geoelectric resistivity (Res) and induced polarization (IP) methods were used in the Torre Target to assist the exploration research through detection of favorable zones of gold mineralization at subsurface of the Castro Basin. The IP results accused a hydrothermal alteration zone delimiting the main ore vein of quartz-adularia, chalcedony and sericite composition, rock where the ore is hosted. Observed resistivity anomalies was of fundamental importance to map and to detect fractures/faults cutting rocky bodies. The results obtained from $2 \mathrm{D}$ and $3 \mathrm{D}$ geophysical data were compared with drilling holes samples and showed good correlation. Also, the work provided a new deposit volume based on values of chargeability.

\section{Introduction and objectives}

The gold occurrences in Castro Basin have been reported since XVIII century. However, due to the lower grade ore and the geological complexity faced, no exploratory project has been successful so far.

Castro mineral deposits were characterized as a lowsulphidation epithermal system, according Seoane (1999), that interpreted that high-grade ore mineralization zones of $\mathrm{Au}$ are associated with quartz veins and shallow intrusions below normal faults. The main ore zone also occur in the lower contact of rhyolite domes and hydrothermal altered zones inside a siltstone lithology. A positive correlation was interpreted observed between the silica increase reaching the maximum gold contend in the silexites-like rocks according to CPRM (2016).

This proposed geophysical study aims to indicate likely zones of gold mineralization in subsurface through Induced Polarization (IP) and DC resistivity (Res) anomalies. Previous studies (Feebay 1989, Allis 1990, Irvine e Smith 1990, Morrell et al, 2011) identified association between argillitic alteration and low content of metallic sulfide in the metallic ore on deposits of this type. This known feature can be correlated with high IP responses considering membrane polarization effect (Orellana 1974). This is an indicative considering that the background is usually low in chargeability. Considering these characteristics, the main objective is to apply geophysical as an aid to map and detects in depth levels geologic discontinuities and lithologies variation as related ore occurrences.

\section{Study Area}

The study area is located in the named Torre target near the Castro city delimited by the polygon with coordinates 597.559E / 7.255.571N; 598.169E / 7.254.127N; 597.130E / 7.253.673N; 596.575E / 7.255.069N (UTM system WGS 84 datum, 22J Zone). The total area has $0,851 \mathrm{~km}^{2}$ and an elevation average of 1017 meters (Figure 1).

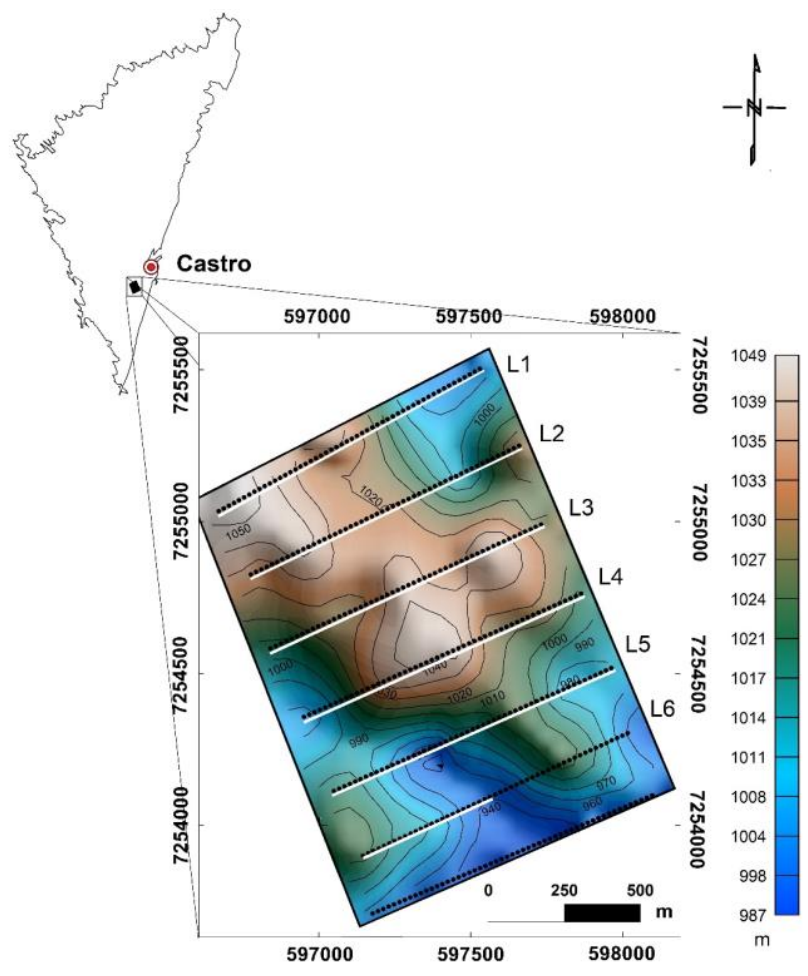

Figure 1- Torre target location map with topography shaded and contours (grey lines) with $10 \mathrm{~m}$ of interval elevation, geoelectric profiles (white lines) and measured stations (black dots).

The Torre deposit has a total ore reserve valuated on $4,055,861$ tons with an average gold grade of $0.43 \mathrm{~g} / \mathrm{t}$ for a cut-off of $0.2 \mathrm{~g} / \mathrm{t}$ or $1.74 \mathrm{t}$ of $\mathrm{Au}$ inside (Piekarz 1999). Today, Torre target is being explored by the Verdau Gold company who discovery Au in sub-horizontal quartz veins in a tabular shape with dimensions ranging from 10 to 200 meters width on a comprised by a kaolin and sericite halo surface, product of intense argillitic and silica hydrothermal alteration. Also, was confirmed small amount and disseminated gold in breccias and volcanic acid rocks (CPRM 2016).

\section{Geologic Setting}

Located in the Paraná State, south region of Brazil, the Castro Basin is a Neoproterozoic rift manifested by an 
extensional regime (Almeida et al 2010, Abreu et al 2013 and 2014), composed mainly by rhyolite, andesite and volcanoclastic acid and intermediate rocks. According Mineropar (2006) five important units of the Castro Group are recognized: (I) Lower Sedimentary Association (OiCsi): Arcosian sandstones and siltstones; (II) Upper sedimentary association (OiCss): Alluvial fans of polymorphic conglomerates; (III) Volcanic Acid I (OiCva2): Quartz, breccia, tufts, ignimbrites; (IV) Volcanic Acid II (OiCva1): Rhyolites and (V) Volcanic Acid-Intermediate (OiCvi2): Andesites, volcanic tuff, ignimbrites and subordinate conglomerates. In addition to the Castro Group, the basin is contemplated by the mica and feldspar sandstones of the Furnas Formation (Df) of Paraná Group, by the undifferentiated Holocene alluvial deposits (Qha) and by Mesozoic basic dikes (JKdb) (Figure 2).

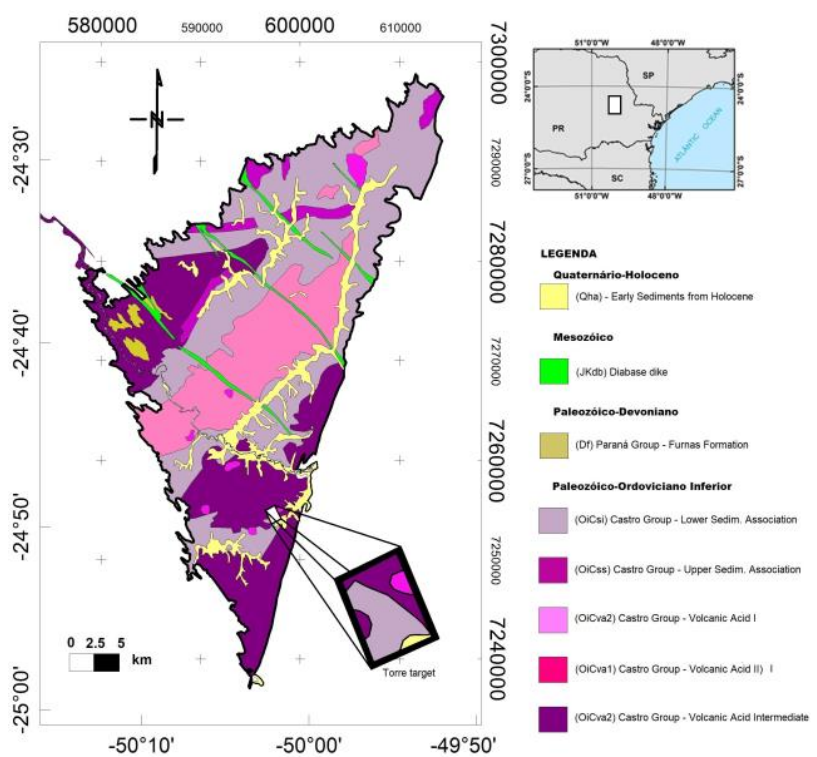

Figure 2 - Geologic context of Castro Basin.

\section{Methods}

In the field, the topographic survey acquisition and stations positioning was performed prior to the geoelectric survey. The data acquisition first step consisted by using a portable GPS to define the first point of each profile line and to the following points. On the same line, the direction using a geological compass were marked while the distance measurement between each station was kept fixed by a 25 $\mathrm{m}$ horizontal length rope. The acquisition lines were spaced about 250 meters each other. The precision location (positioning) for each station was made using a precision GPS receiver type RTK for correct horizontal ( $\mathrm{x}$ longitude and $y$ - latitude) and vertical ( $z$ - elevation) prec. A mobile antenna (rover) was adopted to the best satellite position refinement. Thus, the accuracy reached an average error bellow 0.07 meters in open areas (without forest cover) and 1 meter for dense forest cover regions. For this procedure a Leica GPS-RTK model Viva GS-15 equipment from the Federal University of Paraná (UFPR) was used.

The geoelectrical data acquisition was executed using a system with one injector VIP3000W and one receiver ElrecPro 10 channels from Iris Instruments including the electrodes and cables. The equipment also belongs to Laboratório de Pesquisas em Geofísica Aplicada (LPGA) Federal Paraná University (UFPR). Two electrodes were used to inject current in the ground. For electric potential measurements a set of non-polarizable $\mathrm{CuSO}_{4}$ electrodes were employed. All devices were connected with conductive cables. And the dipole-dipole array configuration was chosen, with a $25 \mathrm{~m}$ electrode spacing and 8 investigation levels. The dataset comprises 5 lines of $1 \mathrm{~km}$ length and 1 line of $0,7 \mathrm{~km}$, in a total of 5,7 kilometers of geophysical profiles.
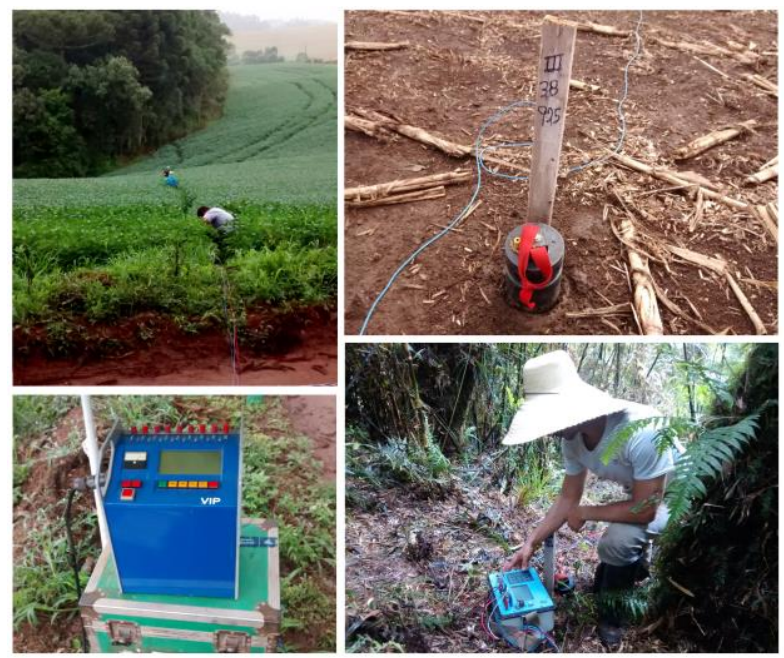

Figure 3- Geophysical data acquisition.

For the DC resistivity and IP inversion the software Zonge $2 D$ Inversion for Interactive ${ }^{\mathrm{TM}}$ IP of Geosoft/Interpex 8.3v was used. Inverted pseudo-sections were generated using 9 iterations, the maximum number allowed. 2D plot sections were generated by interpolation method using $3 x$ 3 meters triangular networks cells with $12,50 \mathrm{~m}$ spacing, which represents the half distance of the original interval spacing, improving, in this way, twice the resolution. 6 profile images were generated representing the "real" chargeability and resistivity behavior in the subsurface rocks. Each IP and Res methods has 55 meters investigation depth (Figures 4 and 5). The voxel as well as the investigation levels maps were generated doubling the maximum theoretical investigation depth. This operation is an automatic Zonge Software procedure that allows depth estimations greater than those calculated by Edward (1977) based on Hallof's projection (Hallof 1957). On both a Triangular Irregular Network interpolator, with cell size of $50 \times 50$ meters was used in the maps and $50 \times 50 \times 50 \mathrm{~m}$ to the voxel (Figure 6). The 3D IP model could be reproduced by the kriging interpolation method (Figure 8).

\section{Results}

\section{D Geophysics}

The IP sections shows high chargeability areas between the stations $0-21$, that are situated between 0 and 500 meters on the profile, specifically between 100-200 meters, in L1 and L2 lines. In L3 the highest and deepest anomaly is checked between 175 and 375 meters. The same patterns can be observed at $L 4$ and the anomaly appears at the beginning of profile, between 125 and 175 meters and also on the 225-300 m interval at L5. These anomalies 
can be correlated to the clay material near the quartz intrusion, both with hydrothermal origins. The IP anomalies are found at shallow levels, being almost outcropping in some areas, but also extending to distances greater than the investigated depth. The upper horizontal anomaly zone with the same physical property, whose thickness exceeds 10 meters at some places and is present in most of the sections can be related to the soil coverage, that is rich in clay due to the rocks of feldspathic composition alteration, a process very common in the local due to the geologic and climatic characteristics of the region. Low chargeability with very high resistivity anomalies is the presumed geophysical signature of rhyolites. These are differentiated in the resistivity sections by the water table by causing the inverse effect, since saturated zones have high conductivity (100-400 Ohm.m) but also do not generate anomalies of chargeability $(<3,0 \mathrm{mV} / \mathrm{V})$. Even knowing the existence of the andesite rock at subsurface, it is not possible to separate them in the geophysical sections since they provide the same resistivities and chargeabilities of a rhyolite. This may have led to a misinterpretation, where some of the signs attributed to rhyolite can refer to the other rock. But, to simplify, no anomaly has been described as andesite, even though it is present.

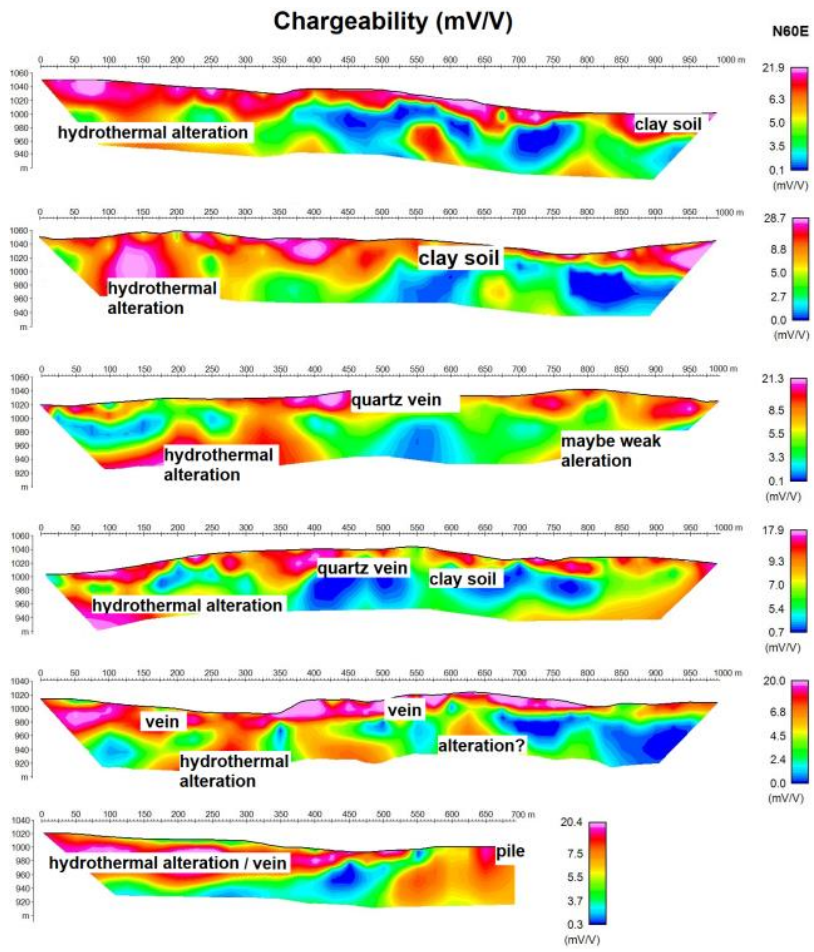

Figure 4- L1-L6 IP sections.

In this context, the main contribution of resistivity results was detecting and mapping fractures, faults and saturated zones, that in 2D images are shown as vertical conductive structures also defining the solid rocks location in general. On L2 profile (725 meters) the rhyolite outcrops presented 2000 Ohm.m. resistivity values. All rocks with equal or superior values was interpreted as the same lithology. In $\sim 500$ m and $\sim 775$ meters there are two main discontinuities which can be frequently observed. At L4, a third, also conductive, discontinuity in a few degrees angle intersect a resistive structure in surface projected at the station 13 (250 meters) can be observed. This feature, also occurs in the L1 (350 meters). Close to these structures high IP anomalies are detected.

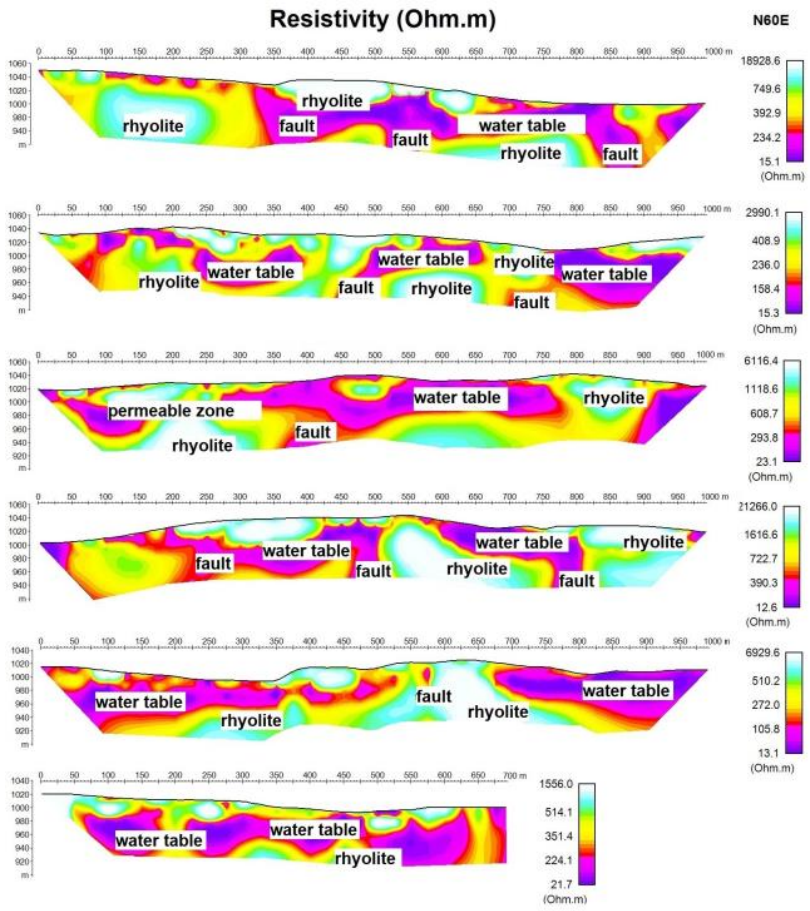

Figure 5- L1-L6 Resistivity sections.

It is observed in the investigation levels maps that the main IP anomaly migrates to south-west, going near the start of the geophysical lines measurements and becomes elongated as the depth increase (Figure 6a).
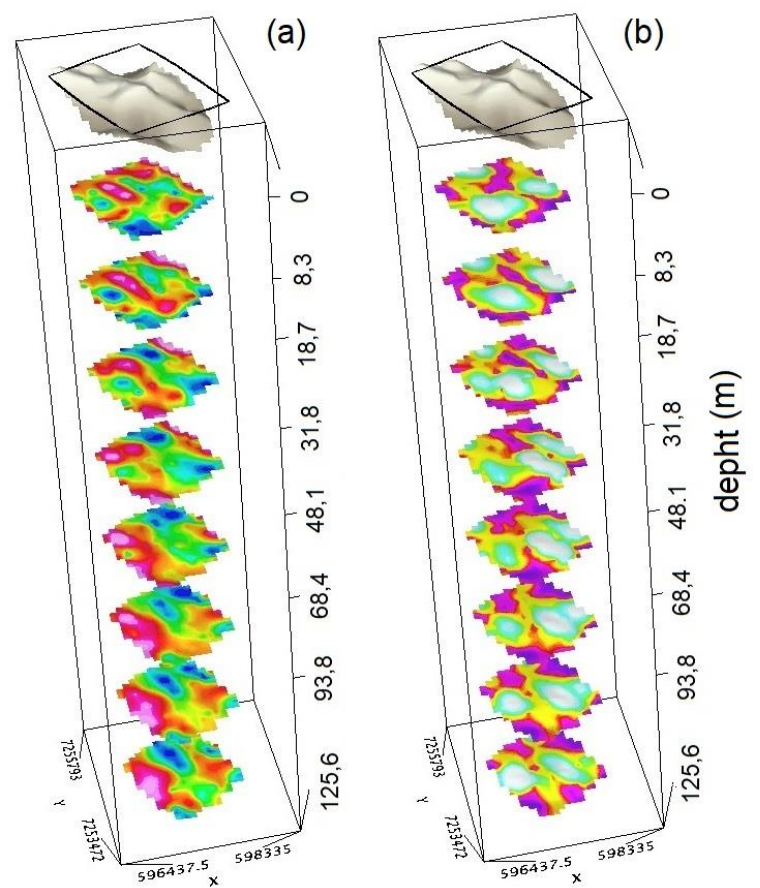

Figure 6 - IP (a) and Resistivity (b) map levels with $2 x$ the investigation depth piled up with the relief model and the polygon on top. 


\section{Drilling and geology}

Drill holes sections were used in the middle portion of $L 3$, where a mineralized quartz vein outcrops to compare with the geophysical results. 01 diamond drill holes (TOFD) and 05 reverse circulation drills (TORC) were drilled close to each another. The selected drill holes locations are showed in Table 1.

Table 1 - Borehole location

\begin{tabular}{|c|c|c|c|c|}
\hline ID Hole & East & North & $\begin{array}{c}\text { Depth } \\
(\mathrm{m})\end{array}$ & $\begin{array}{c}\text { Dip } \\
\left(\theta^{\circ}\right)\end{array}$ \\
\hline TORC13 & 7254767 & 597229 & 44 & 60 \\
\hline TORC16 & 7254770 & 597245 & 87 & 90 \\
\hline TORC17 & 7254782 & 597259 & 32 & 60 \\
\hline TORC18 & 7254761 & 597218 & 44 & 60 \\
\hline TORC20 & 7254791 & 597263 & 36 & 60 \\
\hline TORC21 & 7254774 & 597261 & 36 & 60 \\
\hline TOFD05 & 7254786 & 597269 & 38 & 50 \\
\hline
\end{tabular}

The materials extracted from drill hole cores logging were analyzed individually. Samples were collected every meter, classified and sent to lab to valuate the gold content. Thereby, a geologic section was made reconstructing and interpolating each hole (Figure 7).

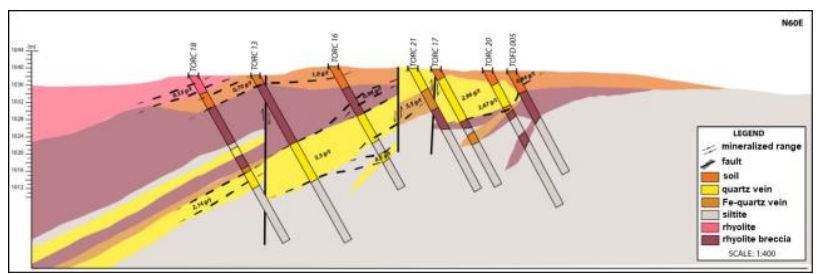

Figure 7 - Geologic section.

\section{D geophysical (IP) models}

The generated voxel is represented sliced almost parallel at L3. In the same line is the location where the boreholes and the outcrop vein are situated (Figure 8).

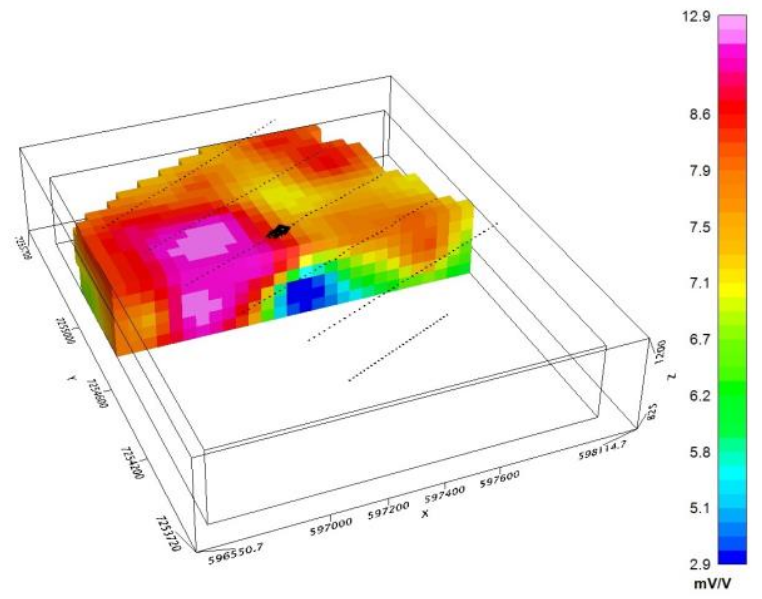

Figure 8 - IP Voxel sliced in the section position showing the $3 D$ chargeability distribution for the model and the boreholes location.
A cross section voxel model for comparison between geologic profile and geophysical modelling was generated and the result presents a good correlation between each other.

Separating in intervals of interest, a solid was created to represent a possible hydrothermal altered zone after separating interesting iso-surfaces (Figure 9). The total surface area was calculated for each interval. The three iso-levels $8 \mathrm{mV} / \mathrm{V}, 9.5 \mathrm{mV} / \mathrm{V}$ and $11 \mathrm{mV} / \mathrm{V}$ have area of $1,017,764 \mathrm{~m}^{2}, \quad 1,017,764 \mathrm{~m}^{2}$ and 1,017,764 $\mathrm{m}^{2}$, respectively, and together represent a volume of $149,750,000 \mathrm{~m}^{3}$ or $0.150 \mathrm{~km}^{3}$.

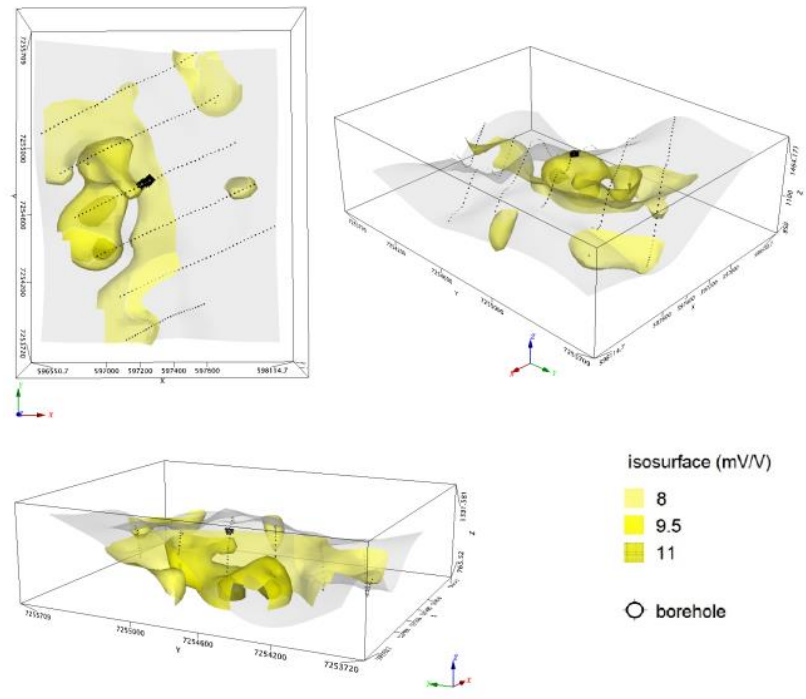

Figure 9-IP 3D showing the anomalous body volume with three different chargeability intervals (isosurfaces). The relief surface and the boreholes location are also showed.

\section{Discussion}

The comparison of the geophysical results and the geological information has a significant correlation. With great agreement. the anomalous IP values are confirmed through drilling holes, characterizing an important sub superficial and unexplored mineralization zone. Results presented by the resistivity method suggests that conductive and vertically anomalies are faults intersecting the rhyolite and andesite rocks. This feature, when compared to IP anomalies, are located in the same structures filled by the quartz-adularia vein related to hydrothermal fluids ducts.

The low sulphidation epithermal systems quartz vein usually are enriched with clay minerals as illite, sericite and adularia, products of hydrothermal processes (Hedenquist 2000). These clays increase and accumulation is probably the responsible for the IP anomalies generation, caused by the membrane polarization effect (Orellana 1974).

Resistivity data suggests the position and extension of rhyolite (or andesite) and faults, which are also an important information for gold occurrence on this prospect. If some Au grade will be found at these boundaries, probably, it found a contact to the quartz vein (Seoane 1999). The rocks resistivity whose value is equal or superior of 2000 Ohm.m, was interpreted according 
previous geological information. There are no resistivity differences between rhyolite, andesite or siltite for the employed methods. It was decided in this study to interpret them all as rhyolite.

We could estimate a $0,150 \mathrm{~km}^{3}$ volume deposit applying geophysics and using to support a geological modeling from the Torre target. Recently, Verdau Gold prospect evaluation using additional RC (reverse circulation) data drilling over these detected anomalies by geophysics modeling increasing the measured resources to $2,500 \mathrm{~kg}$ for the same area, adding more $1,500 \mathrm{~kg}$ of Au. However, for better reliability in geophysical interpretation more holes need to be made.

\section{Conclusions}

Lithologies heterogeneities and structures associated with gold were detected by geoelectric measurements. It was confirmed by geological mapping and drill hole cores. The 3D IP model provided and delineated a larger and unknown deposit volume in the Torre Target.

This study helped to define geophysical signatures to $\mathrm{Au}$ prospection. These indicators will contribute to future prospective studies in the Castro Basin and also in other similar deposits and new drilling exploration program.

\section{Acknowledgments}

We are very grateful to the company Verdau Gold for the partnership and also to CAPES institute for the scholarship granted for the development of this research.

\section{References}

Abreu G.C., Serrano V.D. 2014 A estrutura circular da Fazenda São Daniel - Carambeí - PR. In: SIMEXMIN -VI Simpósio Brasileiro de Exploração Mlneral, Ouro Preto. Sessão Poster. Brasília: ADIMB, v. 05.

Abreu G.C., Serrano V.D., Meloni, R.E. 2013 As Mineralizações Auríferas Epitermais da Bacia de CastroPr. In: Simpósio Brasileiro de Metalogenia, 2013, Gramado, RS. www.ufrgs/sbm. Porto Alegre: UFRS. v. 1.

Allis R.G. 1990. Geophysical anomalies over epithermal system. Journal of Geochemical Exploration, 36, 339-374.

Almeida R.P., Janikian L., Fragoso-Cesar A.R.S., Fambrini G.L. 2010. The Ediacaran to Cambrian Rift System of Southeastern South America: Tectonic Implications. The Journal of Geology: v. 118, p. 145-161.

CPRM. 2016. Occurrence of free gold in hydrothermallyaltered volcanic rocks at Castro Basin, State of Paraná, Brazil: perspectives for new potential areas. Technical report, 8, Brasília, $7 \mathrm{pp}$.

Edwards L.S. 1977. A modify pseudo-section for resistivity and IP. Geophysics, 42(5): 1020-1036.

Feebray C.A., Hishida H., Yoshika K., Nakayama K. 1998. Geophysical expression of low sulphidation epithermal Au$\mathrm{Ag}$ deposits and exploration implications - examples from the Hokusatsu region of SW Kyushu, Japan: Resource Geology, 48, 75-86.
Hallof P.G. 1957. On the Interpretation of Resistivity and Induced Polarization Results. Thesis (Ph. D.) Massachusetts Institute of Technology. Dept. of Geology and Geophysics.

Hedenquist J.W., Arribas A.R., Gonzales-Urin E. 2000. Exploration for Epithermal Gold Deposits, SEG Reviews, Vol 12, 245-277.

Inrvine R.J., Smith M.J. 1989. Geophysical exploration for epithermal gold deposits. Geochemical Exploration, 36, 375-412.

Morrell A.E., Locke C.E., Cassidy J., Mauk J.L. 2011. Geophysical Characteristics of Adularia-Sericite Epithermal Gold-Silver Deposits in the Waihi-Waitekauri Region, New Zealand. Economic Geology, 106, 10311041.

Orellana E. 1974. Prospección geoeléctrica por campos variables. Ed. Paraninfo, 1, 571.

Piekarz G.F. 1999. Relatório final de pesquisa: Processo DNPM 94/826.176. Curitiba: MINEROPAR.

Seoane J.C.S. 1999. Geologia do ouro epitermal de Castro. Tese de Doutorado, Universidade Federal da Unicamp. 1999. 216 pp.

Serrano V.D. 2018. Modelagem geológica e avaliação dos recursos minerais de ouro e prata na Fazenda São Daniel - Carambeí - PR. 2018. Dissertação (Mestrado em PósGraduação em Recursos Minerais e Hidrogeologia) Instituto de Geociências - USP. 